ANDRZEJ SZPULAK

Instytut Filmu, Mediów i Sztuk Audiowizualnych Uniwersytet im. Adama Mickiewicza w Poznaniu

\title{
Podwójne spojrzenie
}

\section{na pewne zdarzenie z przeszłości. O Szpitalu w Cichiniczach Melchiora Wańkowicza $i$ Wrotach Europy Jerzego Wójcika}

\begin{abstract}
Aвstract. Szpulak Andrzej, Podwójne spojrzenie na pewne zdarzenie z przeszłości. O Szpitalu w Cichiniczach Melchiora Wańkowicza i Wrotach Europy Jerzego Wójcika [Double gaze at an event from the past. About Melchior Wańkowicz's Hospital in Cichinicze and Jerzy Wójcik’s The Gateway of Europe]. „Images” vol. XXVI, no 35. Poznań 2019. Adam Mickiewicz University Press. Pp. 117-127. ISSN 1731-450X. DOI 10.14746/i.2019.35.06.

This text confronts two images of a small episode from the First World War and the struggle of Poland to regain its independence. The literary image, Hospital in Cichinicze, is the story of Melchior Wańkowicz (1926), and the film picture is The Gateaway of Europe by Jerzy Wójcik (1999). The film work was an adaptation of literary material; however, the ways memory is created in the two cases are different. Wańkowicz created a somewhat reporter-like, realistic, non-stereotypical record of events, while Wójcik's story was more universal and at the same time more rooted in national symbolism.
\end{abstract}

KEYwORDs: Melchior Wańkowicz, Jerzy Wójcik, war reportage, Polish historical film

Lata 2017-2022 to okres, w którym w polskim życiu publicznym obficie wywoływane są z przeszłości zdarzenia o sto lat wcześniejsze, związane z odzyskiwaniem i utrwalaniem niepodległości Rzeczypospolitej. To zrozumiałe, że problematyka ta przenika także do dyskursu naukowego. Jednakże w przypadku literaturoznawstwa, także wszelkich nauk o sztuce i o kulturze, ośrodkiem zainteresowania stają się nie tyle same zdarzenia historyczne, co artystyczna reakcja na nie - tak reakcja im współczesna, jak i kształtująca się w dekadach późniejszych. Jeśli historia wytwarza bazę pamięci, to wspomniane dyscypliny tę pamięć współtworzą i komentują.

I takim właśnie odniesieniem się do kreacji pamięci będzie niniejszy tekst. Obiektem zainteresowania stanie się podwojony, a ściślej mówiąc - nawet potrojony przekaz dotyczący konkretnych wydarzeń ze stycznia 1918 roku. Chodzi o krótkie, wydane w 1926 roku opowiadanie Melchiora Wańkowicza Szpital w Cichiniczach oraz oparty na jego motywach film Jerzego Wójcika Wrota Europy (1999). Wspomnianym trzecim ogniwem tego łańcucha pamięci, zarazem ogniwem najwcześniejszym, inicjacyjnym, jest pamiętnik uczestniczki ewokowanych wy- 
darzeń, kuzynki pisarza, młodziutkiej Zofii Wańkowiczówny[1]. Oprócz zbudowania podstawowej bazy faktograficznej zdeterminował on formę późniejszego opowiadania. Choćby sposób prowadzenia narracji, która ma charakter pierwszoosobowego, intymnego dziennika spisywanego przez młodą kobietę, relacjonującą i komentującą wydarzenia, w których uczestniczy, ale też zapisującą własne stany wewnętrzne.

Opowiadanie Szpital w Cichiniczach należy do mało znanych utworów Melchiora Wańkowicza, podobnie zresztą jak zapoznany jest wojenny epizod z frontu wschodniego I wojny światowej, do którego się odnosi[2]. W trakcie walk, jakie w styczniu i lutym 1918 roku w okolicach Rohaczewa i Mińska Litewskiego prowadził z bolszewikami I Korpus Polski dowodzony przez generała Józefa Dowbora-Muśnickiego, doszło do spowodowanej zaniedbaniem, dramatycznej sytuacji pozostawienia na łaskę lub bardziej prawdopodobną niełaskę wroga szpitala polowego zlokalizowanego we dworze w Cichiniczach. Zdołano ewakuować lżej rannych i część obsady lecznicy. Pozostały personel wraz z kilkoma żołnierzami podjął się zakończonej kapitulacją obrony. Starsi pracownicy i oficerowie (z wyjątkiem kobiet) zostali rozstrzelani na miejscu, zaś kilka młodych sióstr miłosierdzia, w tym Wańkowiczównę, pozostawiono w Cichiniczach dla opieki nad rannymi, a po kilku dniach wraz z nimi ewakuowano. W ciągu tych dni - mimo kilkakrotnego zagrożenia śmiercią - dziewczęta zdołały doprowadzić do pochowania zabitych[3]. Później szybko udało się im wrócić do domów.

Ten marginalny epizod mało znanej, a współcześnie całkowicie zapomnianej wojennej kampanii na Kresach, tych najmniej zresztą pamiętanych - białoruskich, nosił w sobie znaczący potencjał uniwersalizacji, rezonowania w zbiorowej wyobraźni Polaków. Zawierał się ów potencjał nade wszystko w obrazie młodych kobiet, które, motywowane imperatywem walki o niepodległość, niesienia pomocy rannym i chorym polskim żołnierzom, wykazały się niezłomnym poczuciem obowiązku, odwagą, godnością w obliczu śmiertelnego zagrożenia, odpowiedzialnością za siebie nawzajem. Zawierał się on w martyrologicznym motywie ofiary z życia, jaką złożyli zamordowani lekarze i sanitariusze. A także w silnie utrwalonej w zbiorowej świadomości konfrontacji reprezentowanego przez Polaków europejskiego świata wartości z wschodnim barbarzyństwem zespolonym z pogardzaną bolszewicką ideologią (element ten podkreślił Jerzy Wójcik już w tytule swojego filmu).

[1] Z. Romerowa, Pamiętnik Zofii Wańkowiczówny z polowego szpitala w Cichiniczach. Rok 1918, Montreal 2002.

[2] Jest ono traktowane przez historyków jako jeden z podstawowych dokumentów dotyczących wydarzeń w Cichiniczach, pomocny np. w ustaleniu listy zamordowanych. A. Konopka, Szpital Polowy Polskiego KomitetuPomocy Sanitarnej, „Studia Podlaskie” 1999, t. IX, s. 73-79.
[3] Po ponownym opanowaniu tych terenów przez Polaków odbyła się ekspedycja karna do Cichinicz. Ukaranych zostało kilku chłopów uczestniczących w rozstrzelaniu personelu szpitala. Ofiary ekshumowano i przeniesiono do twierdzy w Bobrujsku. Ibidem, s. 77-78. 
W artystycznej manifestacji tego historycznego epizodu swój udział miała oczywiście także jego fabularna atrakcyjność. Zainteresowanie mógł budzić opis pierwszego zetknięcia Polaków z nową formą państwa rosyjskiego, tą, która już dwa lata później pozwoliła mu na podjęcie próby zniszczenia odrodzonej Polski, a dwie dekady później na skuteczną i dość trwałą realizację tego strategicznego celu. Zainteresowanie tym większe, iż bohaterkami są bezbronne kobiety, znajdujące się w mocy doszczętnie zbarbaryzowanego monstrum i zaglądające do jego wnętrzności, kobiety w szczególny sposób, bo także w sferze seksualności, narażone na demonstrację jego dominacji. Nic by to wszystko jednak nie znaczyło, gdyby nie powstał wspominany zapis sanitariuszki. Zdarzenie w Czichiniczach jest zaledwie - żeby posłużyć się terminem Wańkowiczowym - strzępem wojennej, kresowej epopei, „nigdy niekończącej się, rwanej i kontynuowanej od stuleci”[4]. Taką właśnie refleksją pisarz kończy zarówno krótką przedmowę, jak i samo opowiadanie.

Co mogło skłonić autora Na tropach Smętka do zbeletryzowania tekstu kuzynki? Z pewnością jego zaangażowanie w obecną w nim tematykę, wynikłe z miejsca pochodzenia (białoruskie Kresy, po pokoju ryskim oddane ZSRR) i z własnych doświadczeń wojennych[5]. Owemu zainteresowaniu dał wyraz przede wszystkim w bardziej znanym swym dziele, przywołanych Strzepach epopei (1923), ale zamanifestował je w cytowanej wyżej przedmowie do Szpitala.

Pomysł wziął się również z aktualności tematu. Walki I Korpusu były w międzywojniu, a szczególnie w jego pierwszych latach, dobrze pamiętane, a utrata części wschodnich terenów dawnej Rzeczpospolitej i pozostawienie „za kordonem” dużej grupy Polaków miało charakter przeżycia traumatycznego. Zakończenie przedmowy sformułowane zostało następująco: „Nie ma już tych Kresów. Więc niechże im, niby wiązanka białego kwiecia, na grób padnie to opowiadanie"[6].

Ryszard Kapuściński sformułował przed laty następującą uwagę: „Kiedyś Wańkowicz napisał o sobie [...], że jest pierwszym pisarzem polskim pracującym na zamówienie społeczne. Był mistrzem reportażu, a reportaż z samej swej istoty jest formą opowiadania na zamówienie społeczne"[7]. Uwaga ta odnosi się do wspomnianego aspektu aktualności tematu, ale wskazuje równocześnie na zagadnienie podstawowe - reporterski albo szerzej - dokumentalny idiom twórczości pisarza rodem z Kalużyc. W zapiskach z Cichinicz, uzupełnionych o czynioną z perspektywy kilku miesięcy ustną relację ich autorki (o czym za chwilę), znajduje on znakomitą pożywkę dla swojej pasji odsłaniania rzeczywistości, bo przecież stanowią one tworzony na gorąco obraz zdarzeń, a jednocześnie pozwalają na śledzenie autentycznej, a przy

[4] M. Wańkowicz, Szpital w Cichiniczach, [w:] idem, Strzępy epopei, Szpital w Cichiniczach, Wrzesień żagwiący, Po klęsce, Warszawa 2009, s. 153.

[5] Melchior Wańkowicz był żołnierzem Korpusu Dowbora-Muśnickiego.
[6] M. Wańkowicz, op.cit., s. 154.

[7] R. Kapuściński, O Wańkowiczu, „Kultura” 1974, nr 38, s. 9. 
tym intymnej reakcji na nie ich uczestniczki i świadka. Dzięki temu można było uzyskać podwójny wgląd w opisywany skrawek czasoprzestrzeni. Tak to komentował autor: „Dopieroż czytając, a notując skrzętnie, po tych kolkach epicznych, spisanych w noce bezsenne, w obliczu śmierci i hańby, rozpiąłem żywą opowieść z opowiadań i dopełnień narratorki" [8]. W istocie więc pojawiła się tu reporterska metoda pracy. Oczywiście nie powstała $\mathrm{z}$ tego wielogłosowa panorama znana $\mathrm{z}$ innych utworów pisarza, ale, po pierwsze, nie pozwalały na to uwarunkowania zewnętrzne, a po drugie, jej formuła dopiero się wszakże kształtowała. W tym kontekście nie byłoby niedorzeczne określenie Szpitala w Cichiniczach mianem poważnego ćwiczenia warsztatowego.

Forma dziennika narzuciła beletrystyczny charakter utworu. Subiektywna narracja niosła w sobie wymykającą się schematom, zindywidualizowaną warstwę refleksyjną oraz - w większej mierze - impresyjną, jak choćby w opisie spaceru po wiejskim cmentarzu:

Zatrułam się tymi Cichiniczami, tą martwotą, tym niepokojem strasznym, tą biernością przeklętą. To straszne, tak się czuć strutą jak dzisiaj. Ani cmentarz nie uspokoił, ani nie przestraszył. Siadłem na pniaku i rozumiałam, że oto tu gnije ścierwo ludzkie, nikomu niepotrzebne, wyrzucone[9].

Jednakże w miarę upływu zdarzeń dominującą rolę odgrywać zaczęła relacja skupiona na skrzętnym przywoływaniu chwilowych emocji i drobnych, często nietypowych faktów składających się na subiektywny zapis kilku dramatycznych dni:

Dziś pół dnia leczyłyśmy na wsi. Przyszedł towarzysz Anczew - ten co nas obronił, gdy nas chciano zasypać z trupami. Kazał Halce wziąć wszystko do opatrunków potrzebne i iść z sobą. Dokąd on prowadzi Halkę. Wyskoczyłam za nimi, dopadłam na drodze. Zgodził się wziąć i mnie. Okazało się, że prowadzi do jednej z chałup, w której czteroletni chłopczyk pokaleczył się, spowodowawszy wybuch granatu[10].

W ogólnej swej wymowie, w zastosowanej retoryce, bo nie w konkretnym odniesieniu historycznym, opowieść o zdarzeniach cichinickich wpisywała się dobrze w charakter polskiej pamięci:

Tragiczne dzieje szpitala wojskowego I Korpusu w morzu rewolucji i rewolty chłopskiej na Mohylewszczyźnie - pisał Tadeusz Paweł Rutkowski opisane na podstawie relacji [...] są nie tylko kapitalnym dziełem literackim, ale także porażającym realizmem i plastycznością obrazu dokumentem martyrologii polskiej na „ziemiach zabranych”, które zwłaszcza po drugiej wojnie światowej zostały w dużym stopniu wymazane ze zbiorowej pamięci Polaków[11].

Jednakowoż w szczegółach mogła ta opowieść zaskakiwać nieadekwatnością niektórych opisów czy ludzkich portretów:

[8] M. Wańkowicz, op.cit., s. 153.

[9] Ibidem, s. 157-158.

[10] Ibidem, s. 185 .
[11] T.P. Rutkowski, Wstęp, [w:] M. Wańkowicz, op.cit., s. 6-7. 
Okrucieństwo bolszewików pokazane zostało przez Wańkowicza bez zapiekłości i nienawiści - ciągnął Rutkowski - momentami wręcz chłodno, jako coś oczywistego. [...] Nawet $\mathrm{w}$ tym niemalże piekle ludzkich namiętności i prymitywnych instynktów pokazuje Wańkowicz zachowania ludzkie także po drugiej stronie, dzięki którym epopeja szpitala zakończyła się szczęśliwie[12].

Wańkowicza wiodła w tym wypadku nie tyle jakaś idea postulująca spojrzenie ponadnarodowe, co po prostu wierność materii rzeczywistości, ze swej natury niedającej się w pełni okiełznać symbolicznym matrycom pamięci. Tym było to dla niego łatwiejsze, że doświadczenie sowieckiego komunizmu prezentowało się w momencie powstawania tekstu Wańkowiczówny bardzo skąpo, a kilka lat później - mimo roku 1920 - także raczej skromne w porównaniu do ukształtowanego przez następne dekady, a odziedziczonego przez Jerzego Wójcika. Pisarz odnosił się do rzeczywistości in statu nascendi, zaś reżyser widział tę rzeczywistość ex post.

Szpital w Cichiniczach przed wybuchem wojny był wznawiany, lecz w czasie Peerelu - z oczywistych względów - pozostawał poza oficjalnym krajowym obiegiem. Trzeba powiedzieć, że - pomimo popularności twórcy - był utworem szerzej nieznanym. Mogłoby się wydawać, że z powodu hermetyczności tematyki historycznej pozostanie takim także po 1989 roku. Tak się jednak nie stało. Opublikowany został w postaci niewielkiej książeczki w roku 199o[13]. I to właśnie wydanie wpadło w ręce Jerzego Wójcika, który zainteresował się nim jako literacką podstawą przyszłego filmu. Po kilku latach starań udało mu się doprowadzić do jego realizacji[14], mimo iż druga połowa lat dziewięćdziesiątych nie była okresem łaskawym dla tematyki historycznej w polskiej produkcji filmowej. Trzeba zaznaczyć, że pewnej ochronie utworu przed negatywnym odbiorem (także rzecz jasna jego artystycznemu poziomowi) sprzyjały otoczone nimbem zawodowej doskonałości osoby reżysera i operatora (Witold Sobociński), a promocji posłużyły decyzje obsadowe[15].

Nieco wyżej padło pytanie o motywacje autora opowiadania. Ze względu na odległość czasową od opisywanych zdarzeń i brak aktualności tematu powinno być ono $\mathrm{z}$ większą jeszcze intensywnością powtórzone w odniesieniu do reżysera - twórcy ostatniego jak dotąd ogniwa łańcucha pamięci. Wójcik obficie udzielał informacji na ten temat. „Chcę robić filmy - mówił - które dotyczą mojego miejsca,

[12] Ibidem, s. 7.

[13] M. Wańkowicz, Szpital w Cichiniczach, b.m., 1990. Co ciekawe, w 1994 r. w parku cichinickim, na miejscu rozstrzelania personelu szpitalnego i żołnierzy, ustawiono upamiętnienie zbrodni w postaci krzyża, <http://www.swisspunkt.ch/polo/p_ewiden/ euro/Bialorus_lista.pdf $>$ [dostęp 15.01.2019].

[14] J. Wójcik, We wrotach życia, O filmie „Wrota Europy” z Jerzym Wójcikiem rozmawia Seweryn Kuśmierczyk, „Kwartalni Filmowy” 2003, nr 43, s. 151-152.
[15] Chodziło przede wszystkim o role sanitariuszek. Zosię zagrała Alicja Bachleda-Curuś, która zaledwie kilka tygodni przed premierową emisją Wrót Europy pojawiła się na ekranach kin jako Zosia w Panu Tadeuszu Andrzeja Wajdy. Irenę - Agnieszka Sitek, wcielająca się w pierwszoplanową postać popularnej ówcześnie opery mydlanej Złotopolscy. Halę - Kinga Preis, okrzyknięta wschodzącą gwiazdą polskiego aktorstwa filmowego i teatralnego. 
naszego kraju. Wszystko, co go dotyczy, musi zostać opowiedziane. Jeśli nie teraz, to później”[16]. I dalej: „Bardzo ważna jest dla mnie teraźniejszość i to, co pamiętam w teraźniejszości, co wiem o naszej przeszłości. Taka świadomość czasów i zdarzeń powinna znaleźć swoje miejsce na ekranie. [...]. Jeżeli usunie się z naszego życia pamięć, to będziemy tylko podobni ludziom, nie będziemy narodem”. I jeszcze jedna ważna uwaga, odnosząca się do kameralnej i wielowarstwowej formuły utworu: „Muszę też przyznać, że pewne układy kostiumowo-scenograficzne, czy też fabuły, które rokują wysoką oglądalność, zupełnie mnie nie interesują" [17].

Równoważnymi wydawały się zatem dwie wartości. Pierwszą była kwestia pamięci - obrazu przeszłości kreowanego z punktu widzenia teraźniejszości, drugą - przywracania fenomenów przeszłości $\mathrm{w}$ ich pierwotnym sensie. Trzeba powiedzieć, że Wójcik znalazł się w pewnej pułapce, chcąc skutecznie urealnić obie te wartości równocześnie. Zaprogramował bowiem dwa w dużym stopniu sprzeczne ze sobą działania. Z jednej strony trudno, a właściwie niemożliwe byłoby bowiem przywrócić realną pamięć o walkach I Korpusu Polskiego[18] bez odsłonięcia skomplikowanej i zupełnie dla współczesnego odbiorcy nieczytelnej sytuacji historycznej zaistniałej na Kresach w latach 19141918. Zaś tak głęboka analiza historyczna z pewnością poskutkowałaby utratą zainteresowania odbiorców. Reżyser ubolewał przecież, że nawet elity (funkcjonalne), upostaciowane przez pracowników Ministerstwa Kultury, nie mają najmniejszego pojęcia o tych sprawach. „Słuchano mnie jak przybysza $z$ innej planety" - relacjonował[19]. Z drugiej strony, patrząc na przeszłość z punktu widzenia teraźniejszości, musiałby podporządkować obraz zdarzeń w Cichiniczach obowiązującym kanonom pamięci i zgodzić się na utratę niepowtarzalności tychże zdarzeń $\mathrm{i}$ ich usytuowania w konkretnym kontekście historycznym. Z powodu upływu czasu, w sposób naturalny petryfikującego wizje przeszłości, oraz z powodu brutalnej operacji na pamięci dokonanej w Peerelu jego pozycja w porównaniu z Wańkowiczem była bardzo niekorzystna.

Wójcik wymknął się z pułapki, decydując się w praktyce na drugą z podanych wyżej strategii. Stworzył podatny na narodową uniwersalizację portret losu, czytelny w perspektywie pamięci Polaka przełomu wieków. Rzeczywisty czas akcji utworu łatwo mógł zostać wewnątrz niej przetransponowany na bardzo zbliżony okres wojny polsko-bolszewickiej z roku 1920, kiedy to, podobnie jak okolice Rohaczewa dwa lata wcześniej, wschodnie tereny państwa polskiego wpadły przejściowo

[16] Trzeba powiedzieć, iż te zdania okazały się $\mathrm{w}$ dużym stopniu prorocze, gdyż trzy lata po opublikowaniu tego wywiadu rozpoczął się wielki renesans tematyki historycznej w polskim kinie.

[17] J. Wójcik, op.cit., s. 151.

[18] Formacja ta bardzo tylko skąpo pojawiła się w upamiętnieniach związanych z obchodami setnej rocznicy odzyskania niepodległości. W związku z brakiem materiałów audiowizualnych pozostaje nieobecna np. w rocznicowym dokumencie Niepodległość, zrealizowanym przez Krzysztofa Talczewskiego. Dowodzi to tylko wyraźnie, iż dzieło przywrócenia pamięci o konkretnym fenomenie historycznym nie zostało dokonane.

[19] J. Wójcik, op.cit., s. 152. 
w ręce sowieckie i poddane zostały antypolskiemu terrorowi. Przebrzmiała trauma spowodowana utratą „ziem zabranych” łatwo mogła zostać zastąpiona traumą żywą i podobną, choć jeszcze silniejszą, bo dotyczącą większej społeczności i ważniejszych miejsc pamięci, wywołaną odebraniem nam Kresów II Rzeczypospolitej. Kaźń anonimowych lekarzy i oficerów, przede wszystkim dzięki scenie „zatupywania” i maskowania położonego wśród parkowych drzew miejsca pogrzebania ciał, łatwo mogła zostać skojarzona ze zbrodnią katyńską. Aby zaistniała wspomniana scena, trzeba było dokonać znacznej modyfikacji fabuły.

Ramy do bardziej uogólnionego spojrzenia na sprawę szpitala w Cichiniczach stworzyły już napisy, które w trzech odsłonach pojawiły się w pierwszych ujęciach filmu wraz z mapami przybliżającymi miejsce akcji. Padła w nich co prawda nazwa I Korpusu Polskiego, ale skupiały się one nade wszystko nad wykreowaniem mitycznej przestrzeni „wrót Europy”. To przestrzeń pomiędzy Europą właśnie a barbarzyńskim Wschodem. Bywało, że miała ona charakter przechodniego korytarza: „Tędy wojska Napoleona szły na Moskwę. Tędy na zachód parły wojska carskiej Rosji”. Ale częściej to przestrzeń permanentnego konfliktu, w której forpoczty cywilizacji europejskiej, symbolizowane przez „dwór, od początku wojny pusty, teraz na przyjazd szpitala I Korpusu Polskiego wyszykowany i wybielony", broniły do niej dostępu siłom obcym, destrukcyjnym: „Z północy, z południa i ze wschodu ciągnie na ten dwór i umieszczony w nim szpital bolszewicka Czerwona Gwardia”. Tak ukształtowane widzenie świata podtrzymywane było przez cały film, czego znakiem stało się ujęcie płonącej na dziedzińcu reprodukcji Madonny Leonarda da Vinci.

Wydaje się, że Jerzy Wójcik pragnął stworzyć, kolejny po Skardze (1991), audiowizualny portret polskiej dwudziestowiecznej martyrologii. Ale tym razem postanowił wpisać go w utrwalony obraz starcia cywilizacji, w śmiertelny konflikt sposobów widzenia człowieka i świata. Polacy reprezentują w tej optyce tradycję chrześcijańską, opartą na szacunku dla pojedynczej osoby ludzkiej, na poświęceniu dla niej (pozostanie personelu przy chorych), poczuciu własnej wartości, wyzbywaniu się nienawiści (modlitwa doktora Mroczka za nieprzyjaciół), wierności (rezygnacja Zosi z ucieczki), posługiwaniu się bezinteresowną pracą umysłu (prowadzenie przez Zosię dziennika). Bolszewicy zaś i towarzyszący im chłopi białoruscy kojarzą się z lekceważeniem ludzkiego życia, bezwzględnością i systematycznością w jego odbieraniu (rozstrzelanie własnego dowódcy Anczewa), nieprzestrzeganiem najbardziej elementarnych reguł wojny (mord na jeńcach), kierowaniem się instynktownymi i emocjonalnymi odruchami bez żadnej ich weryfikacji (gwałty, przerwany lincz na siostrach), brutalnością (pobicie chłopa-denuncjatora), obojętnością wobec dóbr kultury, nawet własnej (leżące w śniegu połamane ikony).

Takie podejście reżysera było ryzykowne, a jednocześnie znamionowało wysoki poziom jego niezależności. Wpisywało ono przecież Wrota Europy w bardzo tradycyjny dyskurs polskiej pamięci, z całą 
pewnością nienależący do popularnych, promowanych i uważanych za perspektywiczne. Niewiele zmieniał tu fakt, że świat obserwowany był w filmie z narracyjnej perspektywy postaci kobiecej. Postać ta bowiem niosła w sobie głęboki rys heroiczny, z biegiem zdarzeń ujawniający się $\mathrm{z}$ coraz to większą intensywnością. Groziło to co najmniej zarzutami o anachroniczność. Wójcik anachroniczności nie unikał - w filmie pojawiają się relikty pamięci rodem z czasów II RP - ale przede wszystkim konsekwentnie konstruował przekaz, który traktował jako swoją osobistą misję.

Wybór materiału literackiego tylko do pewnego stopnia sprzyjał takim zamierzeniom. Wojenny epizod cichinicki - mimo dramatycznych momentów - skończył się dla młodej bohaterki opowiadania oraz jej towarzyszek szczęśliwie, powrotem do domu. Pozostał epizodem, a nie wydarzeniem ostatecznie przesądzającym los. Dlatego niezbędne okazały się daleko posunięte i odpowiednio ukierunkowane modyfikacje adaptacyjne. A kierunki były - patrząc syntetycznie - dwa, i to względem siebie komplementarne.

Pierwszy polegał na ograniczeniu żywiołu reportażowego, ale także szerzej - realistycznego. Niwelowało go już samo oddalenie w czasie wizualizowanej historii. To jednak okoliczność obiektywna. Zabiegiem ściśle estetycznym było ograniczenie sfery rodzajowości, dającej oddech w dramatycznym biegu zdarzeń, osadzającej je w namacalnej realności. Nie ma więc sceny współgrabienia przez bohaterki - wraz z okolicznymi chłopkami - własnych bagaży, sceny potocznej, ale jednocześnie tak absurdalnej, że aż śmiesznej, Nie ma zapobiegliwego ukrywania we własnym ubraniu porcji strychniny, przeznaczonej na wypadek napaści seksualnej. Nie ma wypraszania u prowizorycznych władz zgody na pogrzeb rozstrzelanych. Nie ma opatrywania zranionego wiejskiego dziecka. Sfera codzienności, także codzienności kilkudniowej niewoli, pojawiająca się wyrazicie w opowiadaniu, tutaj została zmarginalizowana.

Przytaczane w filmie urywki literackiego monologu Zosi dotyczyły jej stanów wewnętrznych, jej refleksji. Kamera kilkakrotnie pokazywała jej twarz zza okiennej szyby, jej spojrzenie penetrujące świat zewnętrzny. Stworzyło to efekt pewnego dystansu między nią a nim. Z uczestnika przeistaczała się w świadka. Zdawała się kontemplować zdarzenia, a jej działania i stany (na przykład utrata mowy) zdawały się być reakcją na ową kontemplację, odpowiedzią dojrzalszą i głębszą, niż to wynikałoby z treści Wańkowiczowskiego tekstu. Pojawiały się tego rodzaju fragmenty także w opowiadaniu, lecz w o wiele mniejszym stężeniu, i w miarę upływu czasu coraz rzadziej. Bohaterka raczej wyzwalała się stopniowo ze swej wewnętrzności, niż w nią wchodziła. W filmie odwrotnie.

Drugi kierunek modyfikacji adaptacyjnych polegał na wykreowaniu opowieści o wymiarze symbolicznym. Jej treścią było dojrzewanie do heroicznej, ofiarnej śmierci. Aby taka opowieść mogła się urzeczywistnić, potrzebna było specyficzne jej ustrukturyzowanie, nieobecne $\mathrm{w}$ adaptowanej prozie. 
Fabuła rozpoczyna się przyjazdem roześmianych, stosunkowo beztroskich dziewcząt w słoneczny, mroźny dzień na placówkę w Cichiniczach. Potem, podczas wizyty w Rohaczewie, Zosia próbuje rozstać się z towarzyszkami i służbą, by szukać brata, ale przymuszona do powrotu, już kilka godzin później decyduje się zostać przy chorych w szpitalu bez względu na konsekwencje. Po zajęciu szpitala przez czerwonogwardzistów rozmawia $\mathrm{z}$ Anczewem, pozostając obojętną na jego ideologiczne perswazje. Obmywa zgwałconą Irenę. Widzi zakopywanie ciał zamordowanych. Protestuje. Traci mowę. Odzyskuje ją dzięki starej, „widzącej” kobiecie, od której otrzymuje znak wybrania - krzyż. Po wyprowadzeniu z Cichinicz przez Anczewa wraca na miejsce spustoszone śmiercią, w którym rozegrała się orgia zbiorowych gwałtów i zabójstw. W ostatnich kadrach wchodzi w wielki cień bramy.

Prawie wszystkie przywołane zdarzenia - poza przyjazdem i momentem decyzji o rezygnacji z ucieczki na polską stronę - pojawiły się dopiero w filmie. Posłużyły one wykreowaniu owej symbolicznej drogi ku śmierci, jaką przeszła bohaterka. Można tę drogę w rezultacie nazwać heroiczną, chociażby ze względu na jej dobrowolne podjęcie i konsekwentne na niej pozostanie. Wpisana w kontekst roku 1918 - radosnego faktu odzyskania niepodległości, wskazała ona charakter uporczywej walki kilku pokoleń polskich elit, która do tego zdarzenia doprowadziła. A była to walka pojęta skrajnie maksymalistycznie. Główną w niej bronią okazywały się właśnie wartości duchowe - służba, poczucie honoru, odpowiedzialność, poświęcenie (aż do ofiary z życia). W taki ściśle duchowy, w oczywisty sposób oparty na chrześcijaństwie wymiar przeniósł Wójcik opowiadanie o Cichiniczach.

Funeralną atmosferę wzmagał konsekwentnie i zjawiskowo sfilmowany obraz natury. Jak opowiadał reżyser, ekranowa zima z konieczności (nieodpowiednia pogoda) stanowiła twór sztuczny, powołany do życia w obiektywie kamery przez Witolda Sobocińskiego[20]. To stało się okolicznością sprzyjającą. Portretowi natury brak bowiem było żywego realizmu, czystości, intensywnej bieli śniegu, zimowej rześkości. Przenikała ją mroźna martwota, charakteryzowała nieefektowna paleta barw, nieruchomość. Ludzie - szczególnie w planach dalszych - prezentowali się jak figurki z trudem poruszające się po prawie zastygłej przestrzeni.

Dźwiękowy sygnał narastania sytuacji katastrofy stanowił nieobecny we wspomnieniach Wańkowiczówny lamentacyjny śpiew młodej, niewidomej kobiety, pojawiającej się nie wiadomo skąd w towarzystwie wspomnianej „widzącej” przed cerkwią w Rohaczewie oraz przed dworem w Cichiniczach. Treścią jej śpiewu było katastroficzne proroctwo z Księgi Joela, uzupełnione dwoma wersetami psalmu. Oto wyjątek $\mathrm{z}$ tego tekstu:

Powiedzcie to synom waszym,

a synowie wasi niech powiedzą swoim synom,

[20] J. Wójcik, op.cit., s. 152. 
a synowie ich następnym pokoleniom. [...]

Nadciągnął bowiem naród przeciw mojemu krajowi,

mocny i niezliczony,

zęby jego jak zęby lwa,

a zęby trzonowe ma jak lwica. (Jl 1,3.6)

Biblijne odwołanie wyrwało całe zdarzenie z kontekstu tu i teraz, z kontekstu czasu odzyskania niepodległości, i przeniosło na poziom doświadczenia dwudziestowiecznych kataklizmów historycznych, jakie spotkały Polskę. Przywołane ono zostało z perspektywy końca tego stulecia, a z pewnością nie z perspektywy połowy lat dwudziestych, kiedy powstawał utwór Wańkowicza. W perspektywie tej mieściły się krwawe napaści sąsiadów, okupacje, terror, poniżenie, ale także zdrada. Metahistoryczny, zakotwiczony w dawnych widzeniach prorockich przekaz z natury obcy był tamtemu reporterskiemu spojrzeniu. Oddany w nim został również, tak bliski reżyserowi, a tym razem nieobcy również pisarzowi, imperatyw rozpowszechniania pamięci.

Oczywiście modyfikacje adaptacyjne miały też swój zwykły charakter, polegający na scenariuszowej dramatyzacji, budowaniu scen i sytuacji sprawdzających się w narracji filmowej. Jedną z nich było wzmocnienie i pomnożenie obrazów przemocy, szczególnie przemocy o zabarwieniu seksualnym, praktycznie nieobecnej w tekście opowiadania. Ponieważ jednak obrazy te miały w znacznym stopniu charakter symboliczny, to, intensyfikując przekaz, jednocześnie wpisywały się w strategię odrealnienia. Ale już gorąca dyskusja mężczyzn broniących szpitala nad kwestią kapitulacji, odmłodzenie Anczewa czy też wątek jego bohaterskiej śmierci (stereotyp szlachetnego Rosjanina) dodawały wartości czysto filmowych, koniecznych do wykreowania w procesie adaptacji.

Reżyser skarżył się, iż z powodów szczupłych środków finansowych nie udało mu się wprowadzić do filmu - przynajmniej w tak szerokim zakresie, jak planował - wątków związanych z wielokulturowością terenów, na których rozgrywa się akcja. Pojawiła się jednak scena rozmowy głównej bohaterki z Żydem w Rohaczewie, rozmowa, która w istocie nie przyniosła nawiązania jakiegokolwiek porozumienia, zaświadczyła o braku jakiejkolwiek wspólnoty emocji i myśli. W finale z kolei tekst z księgi Joela zaśpiewany został w kilku językach: polskim, ukraińskim, hebrajskim. Aby nieco jeszcze uwyraźnić efekt spotkania różnych światów, do ról bolszewików Wójcik zatrudnił aktorów z Kijowa. Wszystkie te zabiegi dodały pewnego kolorytu kresowego, znanego z prozy i filmu lat dziewięćdziesiątych, ale nie niosły ze sobą większych konsekwencji znaczeniowych. Wańkowicz traktował te kwestie z większą naturalnością. Dla niego wielokulturowość nie była sprawą przeszła i obcą, lecz rzeczywistością, w której funkcjonował od dziecka. Dlatego portretowanie nie-Polaków ograniczyło się - oprócz czerwonogwardzistów - do białoruskich chłopów, na ogół balansujących na granicy bezwzględności i strachu. Nie było tu żadnej tajemniczej mgiełki. 
Należy zatem na koniec skonstatować, iż kreacja Wójcika tak zasadniczo różniła się od adaptowanego materiału literackiego, że trudno tu mówić o adaptacji sensu stricto. Opowiadanie Wańkowicza posłużyło w tym wypadku bardziej jako inspirujący dokument historyczny niż przekaz artystyczny, bardziej jako punkt wyjścia do odmiennej z natury wizji niż równoprawny tekst. Przy czym wizja Wójcika ze względu na symbolikę oraz afirmację martyrologii mogła się nawet wydawać $\mathrm{w}$ większym stopniu tradycyjna, wyrosła $\mathrm{z}$ ducha międzywojennego postrzegania historii, choć ujęta współczesnym sobie językiem kina. Oczywiście uwaga ta nie jest formułowana jako zarzut. Takie odmienne ukształtowanie materii opowiadania przynosi walor owego tytułowego podwójnego spojrzenia, wewnątrz którego owa podwójność oznacza zróżnicowanie.

Kapuściński R., O Wańkowiczu, „Kultura” 1974, nr 38, s. 9

Konopka A., Szpital Polowy Polskiego Komitetu Pomocy Sanitarnej, „Studia Podlaskie" 1999, t. IX, s. 73-79

Romerowa Z., Pamiętnik Zofii Wańkowiczówny z polowego szpitala w Cichiniczach. Rok 1918, Montreal 2002

Rutkowski T.P., Wstęp, [w:] M. Wańkowicz, Strzępy epopei, Szpital w Cichiniczach, Wrzesień żagwiący, Po klęsce, Warszawa 2009

Stochel W., Melchior Wańkowicz a Białoruś, „Acta Polono-Ruthenica” 2002, t. 7, s. $65-70$

Wańkowicz M., Szpital w Cichiniczach, [w:] M. Wańkowicz, Strzępy epopei, Szpital w Cichiniczach, Wrzesień żagwiący, Po klęsce, Warszawa 2009

Wolny K., Sztuka reportażu wojennego Melchiora Wańkowicza, Rzeszów 1991

Wójcik J., We wrotach życia, O filmie „Wrota Europy” z Jerzym Wójcikiem rozmawia Seweryn Kuśmierczyk, „Kwartalnik Filmowy” 2003, nr 43, s. 151-157 